\title{
Reproductive Health Issues Of Women Living In Slum Areas Of Karachi
}

\author{
Seema Manzoor \\ \& \\ Dua-e-Rehma \\ Women's Studies \\ University of Karachi
}

\begin{abstract}
This study aims to establish the understanding about the reproductive health issues of women living in slum areas of Karachi. It also focuses on the actual problems of women living in slums and their access to health care services. Though women are almost half of the population, but are still the most neglected part of the society. Women in slums are extremely vulnerable to many health issues, because they are considered as the most dysfunctional part of the society. Now the scenario has changed a bit and realization regarding women's reproductive health issues is recognized globally, but still social, economic and cultural aspects are barriers in their way to access health facilities. By using quantitative research method researcher has analyzed different factors and circumstances which these women are experiencing, and the universe of population for this study is chosen as few slum areas of Karachi, Pakistan. Whereas, convenience and purposive sampling techniques of non-probability sampling method is used in order to collect the data by 100 respondents. In Pakistan and across the world, slums have been the characteristics of an urban setting. The concentration of reproductive health issues of women and adverse environmental circumstances within slums is an increasingly important concern for developing countries like Pakistan.
\end{abstract}

Keywords: Women, Slum Areas, Reproductive Health Issues, developing countries

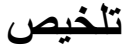

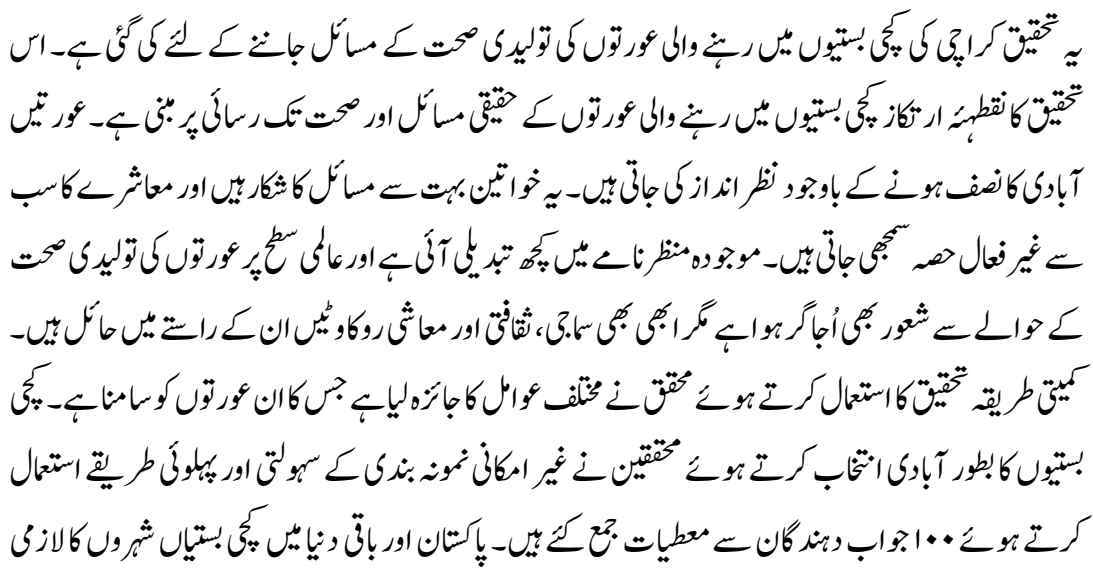




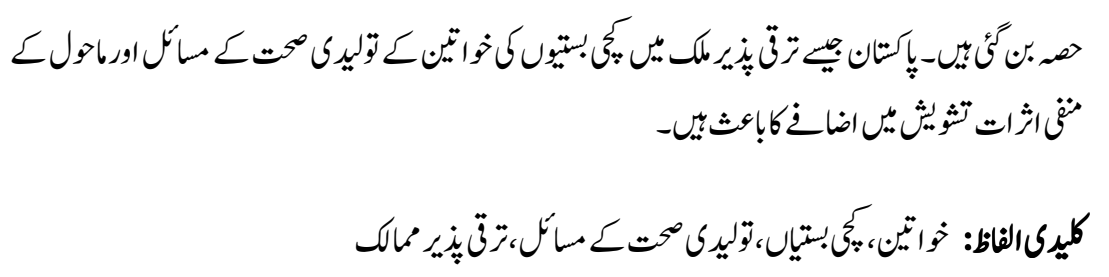

\section{Introduction}

Karachi being a mega-city can be categorized as organized and unorganized population. Unorganized areas are normally called "katchi abadis" (illegal settlements). These illegal settlements are further divided into two types: one is by occupying the state's property illegally, which started at the time of partition, but by the end of 1960's most of them were removed and regularized. And the second type is Informal subdivisions (ISDs), which is again divided into two types: a) regularized by government on lease against payment and b) land occupied illegally, which can be leveled by removing illegal settlers at any stage because state can exercise its power whenever, required for development and government can utilize or can sell off to the private sector also. Sometimes illegal settlers are removed by the government for their safety if the land is not safe for human settlement due to some ecological reasons (Hasan and Mohib, n.d.).

These illegal settlements are mainly due to poverty, and it is not a new trend in Pakistan, almost half of the population out of 190 million people in Pakistan is living below the poverty line since partition. It is quite obvious, that every third Pakistani is compelled to strive and struggling to survive. Every Pakistani knows that Karachi is known as the city of lights and is an economic hub, producing resources to survive for millions, but we must also see the true picture of Karachi i.e. the problems which people face even after contributing in GDP growth of the country. Residents of Karachi do not have the basic necessities, severe traffic issues, law and order situation, and the alarming situation is that the entire population of Karachi is facing these issues no matter which social class they belong. People in kachi abadis living in huts commonly known as jhonpri in Urdu, are going through the worst phase of their life due to their weak financial state and they have no living standard at all, they build their own communities to survive and live in very drastic conditions and are unable to bear the hardships of climate especially women, are bound to live in such inhuman conditions. They literally have no power and due to their unhygienic living conditions their health is always at stake.

Illegal settlements are mainly due to migration from rural areas or internally displaced persons. It is a very usual trend as people move to places where they can earn their living and can generate income. This influx of people causes urbanization and is due to various reasons like getting a job for better living standards. (Chowdhury et al., 2012:124). They come to urban areas in search of 
better living, but are forced to live in slums. Due to urbanization now slums have become the regular part of the city. The slum dwellers are usually the poor people and no country or city can deny such settlements. Today issues of slum areas have grown worldwide because of its issues which are unnoticed i.e. poverty, unplanned housing, illiteracy, dense population and health issues. These issues vary region to region; globally women face more hardships and are of lower status than men, which leaves them more prone to poor and disastrous state. Women also face serious health issues due to an unhealthy environment in which they are forced to survive. Lack of reproductive health facilities, poor sanitation, and the scarcity of other facilities affects their health to the extremes (Nahar et al., 2011: 3). Pregnant women suffer the most due to inadequate food supply, low income, lack of awareness and constant illness. Water borne diseases also cause them serious health issues like cholera, dysentery and other stomach infections, etc. (Rahman, 2013:3; Khan, 2008:255; Ahmed et al., 2010: 265). The slum people live in single room residence or jhonpri known as jhoparh patti, they normally dwell on unoccupied land in the vicinity of railway junctions, railway tracks and near waste dumping areas, which is not adaptable to climatic changes for example rains, floods etc.

These huts are built from alternate construction material from scrap like poor quality wooden panels, plastic material, bamboo, etc. for floors and roofs, and they don't even have sanitary facilities. A separate hut is commonly used by many people as a toilet, which leaves women with no privacy. Municipal taps or illegal water supply from a main water conduit is the water sources available to them where they wash their clothes and dishes which make them more vulnerable to water borne diseases. In some countries efforts are made to provide facilities to slum people in order to organize them and to provide them basic facilities to some extent.

The slum areas close to urban settlements even have no edge and suffer from same conditions; their health is neglected and are no exception. Lack of security, financial instability, no access to medical facilities and other social services becomes more intense with the combination of poverty and physical hardships, have negative effects on the health of women in slums (Das and Shah, 2001).

\section{Common Health Issues among Women in Slum Areas}

Iron deficiency during pregnancy is a common health problem among women in slum areas especially in third world countries like Pakistan (Bakhtiar and Nasar, 2007). WHO has identified that anemia is the root cause of many reproductive issues in women thus, increasing risk of maternal mortality rate (Indowu, Mafian and Sotiloy, 2005). Rate of anemic people has increased to 1.62 billion globally. Due to which worldwide maternal mortality is prevailed to $42 \%$ (Balarajan, Ramakrishnan, Özaltin, Shankar and Subramanian, 2011). Women living in third 
world countries of Africa and Asia are at greater risk (McLean, Cogswell, Egli, Wojdyla and De Benoist, 2009). Maternal mortality rate is increasing due to inadequate dietary practices as well (Scholl, 2005). Low hemoglobin level and reduces quantity of red blood cells is a very common problem seen during pregnancy (Gautam, Saha, Sekhri and Saha, 2008; Balarajan, Ramakrishnan, Özaltin, Shankar and Subramanian, 2011; Barooti et al., 2010).

\section{Review Literature}

Five big cities of South Asia, Delhi, Mumbai, Kolkata, Dhaka including Karachi have established diverse socio-economic and political connections globally. Population of theses five cities is 15 percent of the entire region's urban population and are major contributors of economic, trade, business and various economic activities and yet maintaining the cost of all economic growth innovations being part of the third world countries. These cities have to face many challenges like poor infrastructure, pollution, poverty, violence, etc. (Mahbub, 2014). Slum population has biggest threat in shape of poor health, poverty, lack of civic rights and no access to health facilities and other resources (Ezzati, 2002). Therefore, in such settlements, health remains a secondary issue (Zahid, 1996). According to Marshall (1950) and King and Waldron (1988) unequal distribution of rights among citizens is due to state failure in providing equal status, opportunities and facilities to all masses equally. Whereas, Levitas (1998) and Silver (1994) considers that this unequal distribution of rights is due to economic deprivation and they analyzed that, people having low economic status also have low socio-political status.

The rise of urban slums is basically caused by the increasing trend of urbanization in last few decades and is a very alarming situation in developing countries. Due to migration, urban settlers face scarcity of resources. Some common problems of slum settlers are inflation, poverty, lack of education, and low access to civic rights and health facilities. The known problems in slums in Pakistan and other regions are environmental issues, health hazards; lack of social services, etc. due to urbanization world's urban population has risen from 32 percent in 1950 to 32 percent and is constantly increasing. The latest statistics show that almost half of the global population lives in, or prefer to live in big cities for their economic reasons (World Bank development indicators, 1999). With increase in urban population housing has become a very important need in both economic and welfare sense (World Bank, 1975). According to World Bank (2000) more than 1200 million people live in cities, which shows that people are attracted towards cities due to material benefits. Rapidly growing population is giving rise to slum settlements, and Pakistan is one among the fastest growing populous country.

Kachi abadi residents are poor people who live below the poverty line and lack all basic necessitates of life like education, health and all other social services. Among these settlers, women suffer more due to reproductive role and poor health 
conditions have increased the ratio of maternal mortality. Almost 529,000 die due to pregnancy complications, out of which $90 \%$ maternal deaths occur in developing nations. Millennium Development Goals (MDG) aims to reduce maternal mortality $75 \%$ by the year 2015 (ICPD, 1994). Maternal mortality is a very common problem in developing nations and is because of inadequate food intake, weak financial condition, illiteracy and poor reproductive health. Especially women in rural areas and urban slum settlements become the prey of maternal mortality. To reduce this death toll among women it is necessary to make effective policies and to have a holistic approach regarding women's reproductive health. Reproductive health means that people should have freedom regarding their sexual life that is having a capacity to decide and plan their sexual life according to their desires. Men and women both should have awareness and choice to take-up satisfactory fertility regulations. This choice will allow women to make decisions regarding their sexual life and family planning in order to have a healthy child (WHO, 2011).

Since pregnancy is not any disease, therefore, the mortality rate can be controlled by preventing pregnancy related complications. Maternal deaths occur during the reproductive years, and usually women die due to pregnancy complications, hence it is a need of the time. According to UNICEF (2009) since maternal health status in Pakistan is very low therefore, majority of women face complications or death during pregnancy. Katchi abadi women die due to pregnancy complications due to untrained midwives and other factors like poverty, mal-nutrition, and unsafe birth practices. Karachi has lesser pregnancy related deaths, but in Karachi slums this ratio in increasing everyday due to poor living conditions of these settlements. They don't have access to adequate health services. Being citizens of Pakistan, women in slum settlements also need to live a quality life with all the privileges (Mamdani et al., 2012).

Proper housing is one of the basic rights of citizens and it is the obligation of government to provide them basic facilities. As it was a very popular slogan in 1070 's that food, clothing and shelter is for all. It remained slogan only to gain political benefits; no government ever fulfilled basic needs of people. Slum areas are seen in the neighbourhood of the posh areas reflecting imbalanced image of society and unequal distribution of rights, power and material wealth. This is widening class division even more and people in slums suffer severe health issues due to extreme climatic conditions and sub-standard living, thus, leading towards a life which has no bounties for them and their family. It's not just Pakistan that is facing these issues, it's a global issue. According to World Bank 25 percent of slum dwellers will become 50 percent of the urban population by the year 2035 . Slum areas settlements are unplanned therefore, they face natural disasters like floods, rains, etc. they also become the victim of criminals and the mafia in their areas. They are even sexually exploited (Janjua, 2014). 


\section{Methodology}

This study focuses on the significant health issues of women living in slum areas of Karachi, and the problems they face regarding reproductive health. Lack of education and early marriages also contribute in lowering their health status. Therefore, the study focused on collecting data regarding their health issues by using quantitative research method and descriptive survey method from various squatter settlements. Convenience and purposive sampling techniques of non-probability sampling method are used to collect the data by 100 respondents from various slum areas of Karachi. Interview schedule is used to get the insight and exact situation about the reproductive health issues of women, which are still unattended in order to highlight the affects of sub-standard living and its impact on their lives and health.

\section{Discussion}

This study analyzes the reproductive health issues of women living in slum areas of Karachi. Reproductive health problems have been recognized with the development and change in socio-economic and cultural formation around the globe. Internationally reproductive health considered as a basic human right and to avail this right people must have access to complete reproductive health information and services. In the third world countries like Pakistan a massive increase in population is the root cause of reproductive health problems. In low income status areas one can find families with more children, which could be three and more in number, the preference is having a male offspring. On the broader framework, people living in slums could be attributed as 'class' because they all have the common socioeconomic or educational status.

According to the findings of the study majority of the respondents belongs to the age group of $21-30$ years when they get married, 16\% were from more than 35 years, whereas $10 \%$ of respondents belongs to the age bracket of less than 20 years and only $9 \%$ get married in $31-35$ years of age group. The education level of the respondents shows that $43 \%$ living in the slum areas were illiterate, $22 \%$ were those who had just religious education and can only read nazrah, $16 \%$ were primary pass while $10 \%$ were middle pass and only $9 \%$ were matriculate. The monthly income of these respondents shows different trends according to the nature of their work that $52 \%$ falls in the category of $16,001-19,000,28 \%$ in the category of $13,001-16,000,10 \%$ falls in the category of 10,001-13,000, while 6\% were earning less than 10,000 per month to meet their daily bread and butter needs and only $4 \%$ were those who were earning more than 19,000 Rs. per month. It also reveals that $39 \%$ of the respondents were maids, $32 \%$ were engaged in doing factory work, where as $28 \%$ does packing work and only $1 \%$ was those who were involved in teaching. These percentages indicating distribution of respondent's job; it also shows different typologies of work they were involved in. Data also shows that $75 \%$ of the respondents worked for 10 
hours daily, 20\% were doing 8 hours job and 5\% worked for 6 hours to fulfil the needs of their family members and for themselves. Long working hours and uncomfortable working conditions affects their health and out of hundred percent respondents $63 \%$ were complaining that they had developed backache problem due to their work, $20 \%$ suffered from pain in legs while $16 \%$ said that they were having joint pain and only $1 \%$ reported miscarriage due to their long working hours and constant sitting. It also explains that $80 \%$ of the respondents said that their mental and physical health also affected due to their work and $20 \%$ said that they had no problem and comfortable with their work. While asking about how work effects on their health $62.5 \%$ were complaining stress or tiredness feeling, $17.5 \%$ were effected with muscle cramps and stress whereas $10 \%$ had stress and depression, $8.75 \%$ had multiple problems like muscle cramps, mental tension, stress and depression while $1.25 \%$ reported that they were suffering from mental tension. It also indicates that $94 \%$ of the respondents had $4-6$ numbers of pregnancies while $6 \%$ had $1-3$ numbers of pregnancies while out of hundred percent respondents $93 \%$ falls in the category of 4 - 6 who had given birth to children alive whereas $6 \%$ delivered $1-3$ children alive and only $1 \%$ had cases of miscarriages. It is also very evident that $32 \%$ of the respondents were mal-nutrient while $15 \%$ had taken normal nutrition during pregnancy and only $3 \%$ responded that they had taken good nutrient food during their pregnancy trimester. While general health condition of the respondents was also not much satisfactory. It shows that $61 \%$ of the respondents were complaining nausea feeling during pregnancy, $17 \%$ were complaining that due to excess work load they did not get time to take care of themselves whereas $12 \%$ did not get time for rest and $10 \%$ respondents said that they did not remember to take medicine on time. $70 \%$ respondents were living with weak Immune system, 12\% said that in some cases anaemia causes death during pregnancy while $10 \%$ had given birth to underweight child and $8 \%$ had given birth to anaemic child. All of the respondents said that there is an immense need to take measures at domestic level to prevent mother and child from poor health conditions and $51 \%$ of the respondents said that there is a need to provide healthy atmosphere during pregnancy, 27\% said that there should be proper food intake, $12 \%$ said that do not ignore any type of pain or illness and $10 \%$ said that there is need of providing timely medication to prevent mother and child from poor health issues. $61 \%$ of the respondents were emphasizing that government should provide medical facilities and also create awareness about better health facilities, $18 \%$ were those who said that government should send lady health workers where needed while $14 \%$ said that government should make proper strategies regarding women's health and $7 \%$ said that better transport facilities should be provided by the government.

\section{Conclusions}

The study has been carried out to identify and evaluate the health issues faced by the women living in slum areas, within the family and society. Low status of these 
women identifies many key issues which are unnoticed and are undermined. They face several health issues due to lack of education and lack of awareness. Women living in squatter settlements have poor health conditions and are a victim of feminization of poverty. Among other health issues maternal mortality rate due to early marriages is also very alarming. They live in unhygienic environment with almost nil sanitary facilities. Weak financial status leaves them with no choice but to work and support their family. Extensive work and triple burden leads them to poor health especially in their reproductive years. High rate of fertility increases family size thus, decreasing their health status. Mal-nutrition during early age and reproductive years causes anaemia and several other deficiencies which sometimes even results in miscarriage. Health issues of women living in urban slums cannot be resolved until both public and private sector takes interest and does serious measures to eliminate elements which are key contributors in deteriorating health status of women living in slums.

\section{References}

Ahmed, M., Begum, A. Chowdhury \& M., A. I. (2010). Social Constraints Before Sanitation Improvement in Tea Gardens of Sylhet, Bangladesh. Environment Monitoring Assessment, vol.164:2, pp.263-271.

Bakhtiar U., Khan Y. \& Nasar, R. (2007). Relationship between Maternal Hemoglobin and Perinatal Outcome. Rawal Med J, vol.32, pp.102-4.

Balarajan Y., Ramakrishnan U., Özaltin E., Shankar A.H. \& Subramanian, S.V. (2011). Anemia in Low-Income and Middle Income Countries. The Lancet, vol.17, pp.2123-35.

Barooti E., Rezazadehkermani M., Sadeghirad B., Motaghipisheh Sh., Tayeri S., Arabi M. et al. (2010). Prevalence of Iron Deficiency Anemia among Iranian Pregnant Women; A Systematic Review and Meta-Analysis. $J$ Reprod Infertil, vol.11:1, pp.17-24.

Chowdhury, I. A., Haque, N., Kamal, M. M., Islam, T., Khan, M. M., Islam, M. \& N., Uddin I. (2012). Internal Migration and Socio-Economic Status of Migrants: A Study in Sylhet City, Bangladesh. American Journal of Human Ecology, vol.1:4, pp.123-133.

Das, N.P. \& Shah, Urvi (2001). Understanding Women's Reproductive Health Needs In Urban Slums In India: A Rapid Assessment, M.S. University of Baroda, India.

Ezzati, M., Lopez, A.D., Rodgers, A., Vander, Hoorn S. \& Murray, C.J. (2002). Selected Major Risk Factors and Global and Regional Burden of 
Disease. Lancet, vol.360, pp.347-360.

Gautam C.S., Saha .L, Sekhri K. \& Saha, P.K. (2008). Iron Deficiency in Pregnancy and the Rationality of Iron Supplements Prescribed During Pregnancy. Medscape J Med, vol.10:12.

Hasan, Arif \& Mohib, Masooma (n.d.). The case of Karachi, Pakistan, Pakistan, Architect and Consultant Department.

Indowu O., Mafian C. \& Sotiloy, D. (2005). Anemia in Pregnancy: A survey of Pregnant Women in Abeokuta, Nigeria. African Health Science, vol.5:4, pp.295-99.

International Conference on population and Development, ICPD. (1994). Constraints of Maternity, http://www.jhssuok.com/pdf/Vol.\%202\% 20No.\%201/3CONSTRAINTS\%20OF\%20SAFE\%20MATERNITY.pdf

Janjua, Haroon (2014). Friday Times Weekly: The problem of slums, Pakistan, The Friday Times.

Khan, M., M., H. \& Kraemer, A. (2008). Socio-Economic Factors Explain Differences in Public Health-Related Variables among Women in Bangladesh: A cross-sectional study. BMC Public Health, vol.8, p.254.

King, Desmond S. \& Jeremy, Waldron (2009). Citizenship, Social Citizenship and the Defence of Welfare Provision, British Journal of Political Science, vol.18, pp.415-43.

Levitas, Ruth (1998). The Inclusive Society? : Social Exclusion and New Labour. New York: Palgrave Macmillan.

Mahbub ul Haq (2014). The Rise of Karachi as a Mega-City: Issues and Challenges, Human Development Centre, Policy Briefing Paper.

Mamdani, K.F., Perveen, K., Shahzad, S. \& Siddiqui, N.U. (2011). Constraints Of Safe Maternity: A Leading Cause Of Maternal Mortality In Katchi Abadies (A Case Study Of Karachi). Journal of History and Social Sciences, vol.2:1, pp.45-63

Marshall, Thomas H. (1950). Citizenship and Social Class and Other Essays. Cambridge: CUP. 
McLean E., Cogswell M., Egli I., Wojdyla D. \& De Benoist, B. (2009). Worldwide Prevalence of Anemia, WHO Vitamin and Mineral Nutrition Information System, 1993-2005. Public Health Nutr, vol.12:4, pp.444-54.

Nahar, S., Banu, M. \& Nasreen, H. E. (2011). Women-Focused Development Intervention Reduces Delays in Accessing Emergency Obstetric Care in Urban Slums in Bangladesh: A Cross-Sectional Study. BMC Pregnancy and Childbirth, vol.11, p.11.

Rahman, M. A. (2013). Improvement of Health, Hygiene and Nutritional Status of Urban Slum Dwellers. A Program of RCE Greater Dhaka, Bangladesh.

Scholl, T.O. (2005). Iron Status During Pregnancy: Setting the Stage for Mother and Infant. Am J Clin Nutr, vol.81.

Silver, Hilary (1994). Social Exclusion \& Social Solidarity: Three Paradigms, International Labour Review, vol.133.

UNICEF. (2009). The state of the world's children 2009:07 Maternal and newborn health, http://www.unicef.org/sowc09/docs/SOWC09-FullReport-EN.pdf.

WHO. (2008). Worldwide Prevalence of Anemia 1993-2005: WHO Global Database on Anemia, WHO, Geneva, Switzerland, http://whqlibdoc.who.int/publications/2008/978 9241596657_eng.pdf.

WHO. (2011). The WHO: The World Heath Statistics, USA, WHO, p. 66.

World Bank (1975). HOUSING, Sector Policy Paper, N.W. Washington, D.C. 20433, U.S.A.

World Bank (1999). World Bank Development Indicators, USA, World Bank.

Zahid, G.M. (1996). Mother's Health-Seeking Behaviour and Childhood Mortality in Pakistan. Pakistan Development Review, vol.35, pp.719-731.

Seema Manzoor is Lecturer in the Centre of Excellence for Women's Studies, University of Karachi.

Dua-e-Rehma is Lecturer in the Centre of Excellence for Women's Studies, University of Karachi. 
Annex

Table: 1

Distribution of the respondents according to the age when they get married

\begin{tabular}{|l|c|c|}
\hline Age Groups in Years & Frequency & Percentage \\
\hline Less than 20 Years & 10 & $10 \%$ \\
\hline $21-25$ Years & 43 & $43 \%$ \\
\hline $26-30$ Years & 22 & $22 \%$ \\
\hline $31-35$ Years & 9 & $9 \%$ \\
\hline More than 35 Years & 16 & $16 \%$ \\
\hline Total & $\mathbf{1 0 0}$ & $\mathbf{1 0 0 \%}$ \\
\hline
\end{tabular}

Table: 2

Distribution of the respondents according to their level of education

\begin{tabular}{|l|c|c|}
\hline Level of Education & Frequency & Percentage \\
\hline Illiterate & 43 & $43 \%$ \\
\hline Nazrah & 22 & $22 \%$ \\
\hline Primary & 16 & $16 \%$ \\
\hline Middle & 10 & $10 \%$ \\
\hline Matric & 9 & $9 \%$ \\
\hline Total & $\mathbf{1 0 0}$ & $\mathbf{1 0 0 \%}$ \\
\hline
\end{tabular}

Table: 3

Distribution of the respondents according to their monthly family income in

\begin{tabular}{|l|c|c|} 
Rupees \\
\hline Monthly Income in Rupees & Frequency & Percentage \\
\hline Less than 10,000 & 6 & $6 \%$ \\
\hline $10,001-13,000$ & 10 & $10 \%$ \\
\hline $13,001-16,000$ & 28 & $28 \%$ \\
\hline $16,001-19,000$ & 52 & $52 \%$ \\
\hline More than 19,000 & 4 & $4 \%$ \\
\hline Total & $\mathbf{1 0 0}$ & $\mathbf{1 0 0 \%}$ \\
\hline
\end{tabular}

Table: 4

Distribution of the respondents according to the type of works they are doing

\begin{tabular}{|l|c|c|}
\hline Type of Works & Frequency & Percentage \\
\hline Maid & 39 & $39 \%$ \\
\hline Packing Girl & 28 & $28 \%$ \\
\hline Factory Worker & 32 & $32 \%$ \\
\hline Private School Teacher & 1 & $1 \%$ \\
\hline Total & $\mathbf{1 0 0}$ & $\mathbf{1 0 0 \%}$ \\
\hline
\end{tabular}


Table: 5

Distribution of the respondents according to their working hours

\begin{tabular}{|l|c|c|}
\hline Working Hours & Frequency & Percentage \\
\hline 6 Hours & 5 & $5 \%$ \\
\hline 8 Hours & 20 & $20 \%$ \\
\hline 10 Hours & 75 & $75 \%$ \\
\hline Total & $\mathbf{1 0 0}$ & $\mathbf{1 0 0 \%}$ \\
\hline
\end{tabular}

Table: 6

Distribution of the respondents according to the effect of the job on their health

\begin{tabular}{|l|c|c|}
\hline Effect of Job on their Health & Frequency & Percentage \\
\hline Backache & 63 & $63 \%$ \\
\hline Pain in Legs & 20 & $20 \%$ \\
\hline Joints Pain & 16 & $16 \%$ \\
\hline Miscarriage & 1 & $1 \%$ \\
\hline Total & $\mathbf{1 0 0}$ & $\mathbf{1 0 0 \%}$ \\
\hline
\end{tabular}

Table: 7

Distribution of the respondents according to do they face any physical and mental problem due to work

\begin{tabular}{|l|c|c|}
\hline Face any Physical and Mental Problem & Frequency & Percentage \\
\hline Yes & 80 & $80 \%$ \\
\hline No & 20 & $20 \%$ \\
\hline Total & $\mathbf{1 0 0}$ & $\mathbf{1 0 0 \%}$ \\
\hline
\end{tabular}

Table: 7.1

Distributions of the respondents according to, if yes then any what are the effects

\begin{tabular}{|l|c|c|}
\hline What are the Effects & Frequency & Percentage \\
\hline Mental Tension & 1 & $1.25 \%$ \\
\hline Stress / Tiredness & 50 & $62.5 \%$ \\
\hline $\begin{array}{l}\text { Muscle Cramps, Mental Tension, Stress and } \\
\text { depression }\end{array}$ & 7 & $8.75 \%$ \\
\hline Muscle Cramp and Stress & 14 & $17.5 \%$ \\
\hline Stress and Depression & 8 & $10 \%$ \\
\hline Total & $\mathbf{8 0}$ & $\mathbf{1 0 0 \%}$ \\
\hline
\end{tabular}


Table: 8

Distribution of the respondents according to numbers of pregnancies

\begin{tabular}{|l|c|c|}
\hline Numbers of Pregnancies & Frequency & Percentage \\
\hline $1-3$ & 6 & $6 \%$ \\
\hline $4-6$ & 94 & $94 \%$ \\
\hline Total & $\mathbf{1 0 0}$ & $\mathbf{1 0 0 \%}$ \\
\hline
\end{tabular}

Table: 9

Distribution of the respondents according to the number of children delivered alive

\begin{tabular}{|l|c|c|}
\hline Number of Children Delivered Alive & Frequency & Percentage \\
\hline $1-3$ & 6 & $6 \%$ \\
\hline $4-6$ & 93 & $93 \%$ \\
\hline Miscarriage & 1 & $1 \%$ \\
\hline Total & $\mathbf{1 0 0}$ & $\mathbf{1 0 0 \%}$ \\
\hline
\end{tabular}

Table: 10

Distribution of the respondents according to nutrition/diet during pregnancies

\begin{tabular}{|l|c|c|}
\hline Nutrition/Diet during Pregnancies & Frequency & Percentage \\
\hline Mal-nutrition & 32 & $32 \%$ \\
\hline Normal Nutrition & 15 & $15 \%$ \\
\hline Good Nutrition & 3 & $3 \%$ \\
\hline Total & $\mathbf{1 0 0}$ & $\mathbf{1 0 0} \%$ \\
\hline
\end{tabular}

Table: 11

Distribution of the respondents according to their general health condition during pregnancy

\begin{tabular}{|l|c|c|}
\hline General Health Condition during Pregnancy & Frequency & Percentage \\
\hline $\begin{array}{l}\text { Due to Excess Work Load do not Get Time to } \\
\text { Take Care of Our Self }\end{array}$ & 17 & $17 \%$ \\
\hline Do Not Remember to Take Medicine On Time & 10 & $10 \%$ \\
\hline Do Not Get Time for Rest & 12 & $12 \%$ \\
\hline Nausea Feeling during Pregnancy & 61 & $61 \%$ \\
\hline Total & $\mathbf{1 0 0}$ & $\mathbf{1 0 0 \%}$ \\
\hline
\end{tabular}


Table: 12

Distribution of the respondents according to what problems women face due to anaemia

\begin{tabular}{|l|c|c|}
\hline Problems they Face Due to Anaemia & Frequency & Percentage \\
\hline Death during Pregnancy & 12 & $12 \%$ \\
\hline Birth of Anaemic Child & 8 & $8 \%$ \\
\hline Underweight Child Birth & 10 & $10 \%$ \\
\hline Weak Immune System & 70 & $70 \%$ \\
\hline Total & $\mathbf{1 0 0}$ & $\mathbf{1 0 0} \%$ \\
\hline
\end{tabular}

Table: 13

Distribution of the respondents according to what measure should be taken at domestic level to prevent mother and child from poor health issues

\begin{tabular}{|l|c|c|}
\hline $\begin{array}{l}\text { Measures to Prevent Mother and Child from } \\
\text { Poor Health Issues }\end{array}$ & Frequency & Percentage \\
\hline Proper Food Intake & 27 & $27 \%$ \\
\hline Providing Timely Medical Facilities & 10 & $10 \%$ \\
\hline Do not Ignore any type of Pain or Illness & 12 & $12 \%$ \\
\hline Provide Healthy Atmosphere & 51 & $51 \%$ \\
\hline Total & $\mathbf{1 0 0}$ & $\mathbf{1 0 0 \%}$ \\
\hline
\end{tabular}

Table: 14

Distribution of the respondents according to what measures should be taken at government level to provide better health facilities for pregnant women and children

\begin{tabular}{|l|c|c|}
\hline Measure Taken by Government & Frequency & Percentage \\
\hline $\begin{array}{l}\text { Providing Medical Facilities and Raising } \\
\text { Awareness }\end{array}$ & 61 & $61 \%$ \\
\hline Improve Transport Facility & 7 & $7 \%$ \\
\hline Sending Lady Health Workers Where Needed & 18 & $18 \%$ \\
\hline Making Strategies Regarding Women's Health & 14 & $14 \%$ \\
\hline Total & $\mathbf{1 0 0}$ & $\mathbf{1 0 0 \%}$ \\
\hline
\end{tabular}

